\title{
The Presence of Internal Quality Management Strategies in Improving a Culture of Quality
}

\author{
Irawati Sabban*, Abdul Azis Wahab \\ Educational Administration Department, School of \\ Postgraduate Studies \\ Universitas Pendidikan Indonesia \\ Bandung, Indonesia \\ *irawatisabban@upi.edu \\ Yayah Huliatunisa \\ Universitas Muhammadiyah Tangerang \\ Tangerang, Indonesia
}

\author{
Deden Saepudin \\ Sekolah Tinggi Pariwisata \\ Bandung, Indonesia
}

\begin{abstract}
The present study aims to find out the effects of internal quality management strategies in the culture of quality of Pasifik Morotai University using sequential mixed method. Multiple regression analysis was implemented to analyse quantitative data, while qualitative data was analysed using Miles-Huberman analysis. Data was gathered using questionnaires, interviews, field observations, and documentation. The findings of this study indicated that internal quality management strategies did not have significant effect, separately or simultaneously, on the culture of quality in Pasifik Morotai University. Improving the culture of quality in Pasifik Morotai University will require the involvement of professional organizations, employers of graduates (to determine the standard of quality), and structured, planned, and regular training for lecturers and staff. To implement quality management model appropriately, quality management strategies need to be updated in accordance with the existing operational procedure.
\end{abstract}

Keywords-culture of quality, mangement strategies, internal quality management

\section{INTRODUCTION}

Pasifik Morotai University is a private university in Pulau Morotai Regency, North Maluku Province. It offers bachelor degrees in eleven programs in six faculties. Pasifik Morotai University runs the faculties of Social and Political Science, Teaching and Education Science, Engineering, Maritime Science, Economy, and Science and Math. These faculties offer various programs, including State Administration, Elementary School Teacher Education, English, Environmental Engineering, Civil Engineering, Informatics Engineering, Industrial Engineering, Maritime Science, Fish-Finder Technology, Accounting, and Mathematics.

Continuous quality improvement is a major part of quality management. Autonomous higher education institution is responsible for its own quality improvement [1]. Quality higher education produces graduates who are able to actively develop their potentials and create useful knowledge and/or technology for their society and nation [2].

Higher education quality management system involves five stages, Determination, Implementation, Evaluation, Control, and Improvement (DIECI) [3]. In implementing DIECI model, Pasifik Morotai University formulated four internal quality management strategies through its quality management body. Pasifik Morotai University's internal quality management strategies are: (1) actively involving all academics in developing internal quality management system (IQMS); (2) involving professional organizations, alumni, businesses, and government as employers of graduates in determining IQMS standards; (3) providing structured and well-designed trainings to lecturers and staff concerning IQMS, and internal auditor training in particular; (4) periodically disseminating IQMS functions and objectives to stakeholders [4].

Based on field observation, we found several problems that the university was facing. For instance, lecturers' and staff's understanding about quality management system was weak, quality was considered as an expensive thing to get, and the lack of socialization concerning quality management from the quality management body.

Data from Statistics of Pulau Morotai Regency showed that the biggest percentage of unemployed people in the regency held bachelor degrees. Pasifik Morotai University was one of the universities that produced those unemployed graduates. Regarding this, based on the 2017 rank of universities in Maluku and North Maluku Provinces, Pasifik Morotai University's rank went down from the third cluster to the fourth cluster [5] . In terms of accreditation level, nine programs offered by the university were accredited C. Meanwhile, the other two programs, i.e. Mathematics and Fish- 
Finder Technology, were still in the process of accreditation. In its eleven years of service, Pasifik Morotai University's programs was yet to get accredited. The geographical location of Pasifik Morotai University, i.e. in a border region, was a major consideration in inviting lecturers from outside Maluku Island to the university. The lack of lecturers proved to be a problem in the accreditation process. Due to the arduous process of program accreditation, Pasifik Morotai University had only held two graduation ceremony, in 2019 and in 2020. All the while, the university implemented the same quality management strategies [6].

Quality management practices top management commitment and support, organization for quality, employee training, employee participation, supplier quality management, customer focus, continuous support, improvement of quality system, information and analysis, and statistical quality techniques use [7]. Quality management is part of managerialism because it involves every member of the organization. Sustainable culture of quality in providing public services is a requirement for professionals to evaluate their organization and create new mode description [8]. Quality management regulation model in higher education institutions focuses on academic standards, academic quality, academic quality management, and information, which includes collaboration between academics community and government agencies [9]. Every university has substantially different culture, because culture is a pattern of belief and expectation shared by the members of an organization [10]. TQM requires cultural changes. Salis proposes twelve indicators of culture of quality, i.e. vision, commitment, communication, customer needs, openness to critiques, employee development, management and policies, innovation, task analysis, opportunities, effective teams, and monitoring and evaluation [11].

In this study, we focused on answering the question: Is there any effect of internal quality management strategies on the culture of quality of Pasifik Morotai University? This study aims to discover the effects of the four internal quality management strategies on Pasifik Morotai University's culture of quality.

\section{ReSEARCh Methodology}

The present study was designed as a mixed study using sequential mixed methods. The procedure began with quantitative research method of testing a certain concept within certain number of samples, followed by qualitative research method [12]. Sampling technique used in this study was Random Sampling, using Isaac and Michael's table of sample numbers [13]. Total number of lecturers and staff in Pasifik Morotai University was 85 people. Referring to Isaac and Michael's table, with significance level of $5 \%$, the total sample was 68 people.

The independent variables in this study were Pasifik Morotai University's four quality management strategies, i.e. (1) active involvement of all academics from planning and evaluation to development stage of quality management system; (2) involvement of professional organizations, alumni, businesses, and government as employers of graduates, especially in determining internal quality management standards; (3) structured and well-designed training for lecturers and staff on quality management, particularly in terms of being internal auditor; (4) periodically disseminating the functions and aims of quality management to stakeholders. These strategies were then used in developing questionnaire for the present study. The dependent variable, on the other hand, was culture of quality (TQM). The data was analysed using multiple regression analysis in SPSS version 25. The hypotheses of the present study were:

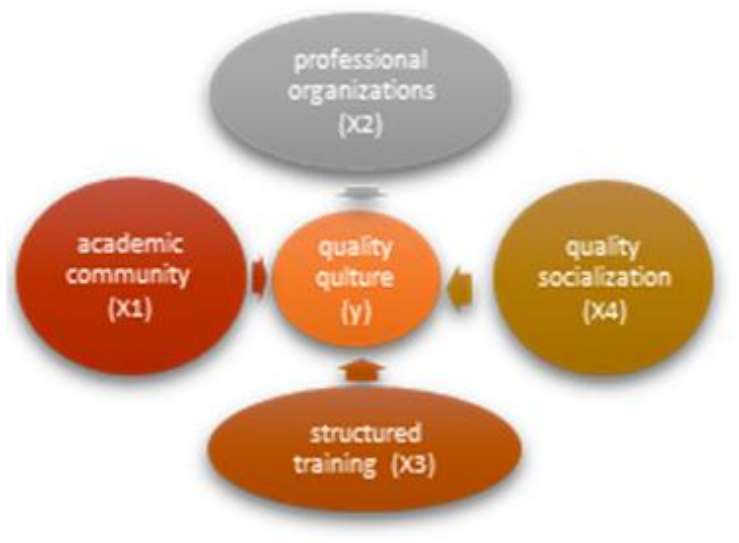

Fig. 1. Correlation between variables.

- H1. There is an effect of academic community (X1) on the culture of quality $(\mathrm{Y})$.

- H2. There is an effect of professional organizations (X2) on the culture of quality (Y).

- H3. There is an effect of structured training (X3) on the culture of quality (Y).

- H4. There is an effect of quality socialization (X4) on the culture of quality (Y).

- H5. There is an effect of quality management strategies (X) simultaneously on the culture of quality (Y).

- Level of confidence $95 \%, \alpha=0.05$

The instrument used was valid and reliable. Validity test using Pearson Product Moment resulted in an instrument with 21 question items. The output data of correlation between item score and total score was compared with the r-table (level of significance 0.05 , total respondent 21 people, and r-table of 0.433 ), resulting in 20 valid items out of 21 questions. Reliability test using Cronbach Alpha resulted in a score of 0.931 . Since it was larger than 0.60 , the questionnaire was considered reliable or consistent. 


\section{FINDINGS AND DISCUSSION}

Data analysis was conducted using Statistical Package for the Social Sciences (SPSS) software version 25. Before hypotheses testing, classical assumption tests were conducted. Classical assumption tests were requirements for multiple regression analysis, consisted of:

\section{A. Normality Test}

Regression model had normal distribution (fig.2), as seen from the plotting of real data that followed a diagonal pattern.

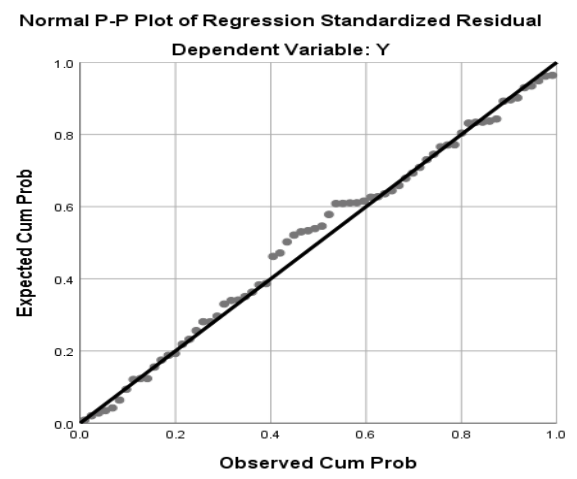

Fig. 2. Normality result in probability plot.

\section{B. Multicollinearity Test}

Tolerance and VIF indicated that there were no signs of multicollinearity if tolerance score $>0,100$ and VIF score < 10,00 (table. 1).

TABLE I. RESULT OF TOLERANCE AND VIF MULTICOLLINEARITY

\begin{tabular}{|l|l|l|l|l|}
\hline \multicolumn{5}{|c|}{ Coefficients $^{\mathbf{a}}$} \\
\hline Mode & T & Sig. & Tolerance & VIF \\
\hline Constant & 4.568 & .000 & & \\
\hline $\mathrm{X} 1$ & .262 & .795 & .953 & 1.049 \\
\hline $\mathrm{X} 2$ & 1.600 & .115 & .754 & 1.326 \\
\hline $\mathrm{X} 3$ & 1.609 & .113 & .745 & 1.343 \\
\hline $\mathrm{X} 4$ & .438 & .663 & .807 & 1.238 \\
\hline
\end{tabular}

\section{Heteroscedasticity Test}

Glejser output (table. 2) indicated that there was no heteroscedasticity because significance value (Sig) between independent variables with absolute residual was higher than 0.05 .

TABLE II. RESUlT OF GLEJSER HETEROSCEDASTICITY

\begin{tabular}{|l|l|l|}
\hline \multicolumn{3}{|c|}{ Coefficients $^{\mathbf{a}}$} \\
\hline \multicolumn{1}{|c|}{ Mode } & \multicolumn{1}{c|}{ Sig. } \\
\hline Constant & -.674 & .503 \\
\hline $\mathrm{X} 1$ & 1.680 & .098 \\
\hline $\mathrm{X} 2$ & .136 & .893 \\
\hline $\mathrm{X} 3$ & .415 & .680 \\
\hline $\mathrm{X} 4$ & .309 & .758 \\
\hline
\end{tabular}

\section{Autocorrelation Test}

Durbin Watson (dw) output was 1.848 (table 3) showed that $\mathrm{du}(1.7335)<\mathrm{dw} 1.848<2.2665$, which meant that there was no autocorrelation.

TABLE III. RESULT OF DURBIN WATSON

\begin{tabular}{|c|c|c|c|}
\hline \multicolumn{4}{|c|}{ Model Summary $^{\mathbf{b}}$} \\
\hline Model & $\mathbf{R}$ & R Square & $\begin{array}{l}\text { Durbin } \\
\text { Watson }\end{array}$ \\
\hline 1 & .249 & .062 & 1.848 \\
\hline \multicolumn{4}{|c|}{ a.Predictors: (constant), $\mathrm{x} 4, \mathrm{x} 1, \mathrm{x} 2, \mathrm{x} 3$} \\
\hline \multicolumn{4}{|c|}{ b.Dependent Variable: Y } \\
\hline
\end{tabular}

Once the classical tests satisfied the requirement, regression test was conducted.

The results of classical tests indicated that the collected data could be further analysed using multiple regression analysis based on the consideration that if sig. value $<0.05$ or t-calc $>\mathrm{t}-$ table then $\mathrm{X}$ variables affects $\mathrm{Y}$ variable, and if sig. value $>$ 0.05 or $\mathrm{t}$-calc $<\mathrm{t}$-table then there is no effect of $\mathrm{X}$ variables on $\mathrm{Y}$ variable, with $\mathrm{t}$-table $=\mathrm{t}(\alpha / 2 ; \mathrm{n}-\mathrm{k}-1)=\mathrm{t}(0.025 ; 63)=1.998$

Based on the result of multiple regression test, the significance value of each variable was as follow (table 4):

TABLE IV. MultiPle REGRESSION TEST RESUlt

\begin{tabular}{|l|c|c|c|}
\hline \multicolumn{1}{|c|}{ Variable } & $\begin{array}{c}\text { Coefficient of } \\
\text { regression }\end{array}$ & $\mathbf{t}_{\text {calc }}$ & Sig. \\
\hline Constant & 18.840 & & \\
\hline $\mathrm{X}_{1}$ & 0.058 & 0.262 & 0.795 \\
\hline $\mathrm{X}_{2}$ & 0.254 & 1.600 & 0.115 \\
\hline $\mathrm{X}_{3}$ & -0.166 & -1.609 & 0.113 \\
\hline $\mathrm{X}_{4}$ & 0.069 & 0.438 & 0.663 \\
\hline $\mathrm{F}_{\text {calc }} 1.039$ & \multicolumn{3}{|l}{} \\
\hline $\mathrm{R}$ Square $=062$ & 0.062 \\
\hline a.Dependent Variable: $\mathrm{Y}$ & \\
\hline
\end{tabular}

Based on table 1, R square was 0.062 or $6.2 \%$. It meant that the percentage of effect contributed by the independent variables on the dependent variable was $6.2 \%$. In other words, quality management strategies in Pasifik Morotai University only contributed $6.2 \%$ towards the culture of quality in the university. The remaining $93.8 \%$ was influenced by other variables. Therefore, there was no significant effect or correlation between quality management strategies and the culture of quality in Pasifik Morotai University. It was determined by the following results:

- Sig. value was $0.795>0.05$ or t-calc was $0.262<\mathrm{t}$-table of 1.998, which meant that X1 variable had no effect on Y variable.

- Sig. value was $0.115>0.05$ or t-calc was $1.600<\mathrm{t}$-table of 1.998, which meant that X2 variable had no effect on Y variable. 
- Sig. value was $0.113>0.05$ or t-calc was $1.609<\mathrm{t}$-table of 1.998, which meant that X3 variable had no effect on Y variable.

- Sig. value was $0.663>0.05$ or t-calc was $0.438<\mathrm{t}$-table of 1.998, which meant that X4 variable had no effect on Y variable.

The consistency of data analysis result was supported by the $\mathrm{R}$ square value on the simple regression output (table 5).

TABLE V. MODEL SUMMARY RESULT

\begin{tabular}{|c|c|c|c|c|}
\hline \multicolumn{4}{|c|}{ Model Summary } & \multirow[b]{2}{*}{$\begin{array}{l}\text { Std. Error of } \\
\text { the Estimate }\end{array}$} \\
\hline Model & $\mathbf{R}$ & $\begin{array}{c}\mathbf{R} \\
\text { Square }\end{array}$ & $\begin{array}{l}\text { Adjusted } \\
\text { R Square }\end{array}$ & \\
\hline 1 & $.249^{\mathrm{a}}$ & .062 & .002 & 3.488 \\
\hline
\end{tabular}

Based on table 5, R square was 0.249 which indicated that there was weak correlation between the independent variables and the dependent variable. It meant that quality management strategies of the university correlated weakly with the culture of quality in the university. Simultaneously, quality management strategies did not have significant effect on the culture of quality in Pasifik Morotai University, as proven by the following output (Table 6).

TABLE VI. ANOVA RESULT

\begin{tabular}{|l|l|l|l|}
\hline \multicolumn{4}{|c|}{ ANOVA $^{\text {a }}$} \\
\hline Model & & \multicolumn{1}{c|}{ F } & Sig. \\
\hline \multirow{3}{*}{1} & Regression & 1.039 & $.394^{\text {b }}$ \\
\cline { 2 - 4 } & Residual & & \\
\cline { 2 - 4 } & Total & & \\
\hline \multicolumn{2}{|l}{ a.Predictors: (constant), X4, X1, X2, X3 } \\
\hline \multicolumn{2}{|l}{ b.Dependent Variable Y }
\end{tabular}

The output of multiple regression analysis showed that sig. value was $0.394>0.05$ or $1.038<$ F-table of 2.52 , which meant that there was no significant effect of $\mathrm{X}$ variables, simultaneously, on Y variable. In other words, the four internal quality management strategies of Pasifik Morotai University (X) simultaneously did not affect the culture of quality (Y) of the university.

In the secondary data from quality management document of the university, the mechanism of DIECI (Determination, Implementation, Evaluation, Control, and Improvement) management model was outlined. Internal Quality Assurance Standards at Morotai Pacific University designed, implemented, and enhanced sustainable quality based on DIECI will result in or continuous quality improvement of higher education quality. With a management model DIECI, each unit in the university environment must periodically conduct self-evaluation process to assess the performance of its own units using procedures. The results of the self-evaluation will be reported to the unit, all staff in the unit concerned, and to the university leadership. Against the results the selfevaluation of unit leaders and university leaders will make decisions about steps or actions that must be taken to improve and improve quality [4].

To facilitate the implementation of quality management system using DIECI management model in Pasifik Morotai University, the four internal quality management strategies were formulated. We interviewed the head of quality management body of Pasifik Morotai University, asking how they implement the quality management strategies. The respondent replied:

"In implementing the quality management strategies, each unit existing within the university must regularly implement the SOP, and have to perform monitoring. Self-evaluation result will then be reported to the leader of the university, in this case is the rector. These self-evaluation results will later be discussed in a management meeting to determine the steps or actions to be taken to increase and improve the quality."

Then, we inquired about the mechanism of involvement for professional organizations and alumni. The head of quality management body stated:

"Pasifik Morotai University has only conducted one graduation ceremony, which means that we do not have alumni. We plan to do data collection this year to register the alumni and build a good relationship with them. Our graduates are now working in various companies, private sectors, and even the government, but (our) contribution is minimum."

In regard to structured and well-designed training for lecturers and staff, the head of quality management stated:

"We are lacking in training activities due to the problems of funding. The fact is, this university still depend $100 \%$ depends on the Regional Budget of Morotai Regency. We know that we are located in the border of North Maluku, and to go outside this island takes a lot of money. Alhamdulillah, we have independent lecturers and staff. Our lecturers often receive research grants or public service from the directorate general of higher education. Some of them also enrolled in pre-service training offered by the directorate general of higher education."

The source of funding for Pasifik Morotai University was the annual grant from the regional government. Morotai Regency provided free education from early childhood to university levels for its citizens. Hence, students enrolling in Pasifik Morotai University were not required to pay anything. On the flip side, the number of students enrolling in the university would affect the amount of grant the university received. The consequence of this was that any activity in the university should be approved by the rector. We asked the head of quality management body about the socialization of quality management in Pasifik Morotai University and he responded: 
"The socialization that we conducted was in the form of creating a quality management team, in which every member is responsible for one faculty. Therefore, we can minimize the costs. We seldom disseminate information about quality management for the public or for all lecturers and staff. This is our socialization strategy."

There is a study to explore the relationship between quality management practices and their impact on performance. First, critical quality management practices are identified and classified in three main categories: management, infrastructure, and core practices. Then, a model linking these practices and performance is proposed and empirically tested. The results reveal a positive relationship between quality management practices and organizational performance [7,14]. The aim of TQM is to achieve customer satisfaction, cost effectiveness, and fault-free [15]. Quality management is a systematic and continuous process [11]. DIECI model exists to manage and improve the quality of university [16]. Aspects that affect the culture of quality through quality management system are influenced by educational policies, which include planning, communication, support and reward, and management process consisting of organizational climate, teaching-learning process, and relationship with users [17]. Consequently, the quality management system in Pasifik Morotai University should be reformulated and evaluated through a series of academic and scientific method. In other words, quality management strategies should be updated to improve the quality of the university. The results of this study provide some references for evaluation and for formulating internal quality management strategies in universities in Morotai.

\section{CONCLUSION}

The internal quality management strategies in Pasifik Morotai University, simultaneously, did not have an effect on the culture of quality developed in the university. In other words, the existing strategies developed by Pasifik Morotai University's quality management body to ensure quality management did not work. The four formulations of Pasifik Morotai University's quality assurance strategy should have been revised and should be implemented in accordance with the planned strategy. The results of this study can be used as an evaluation material in revitasing the quality assurance strategy of Morotai Pacific University. In addition, in order to obtain objective facts about accreditation issues, further research can be done on the impact of internal quality assurance on external quality assurance, can also be done development research on the right quality management strategies in developing quality culture especially in the Pasifik Morotai University.

Conducting quality management system in university using DIECI model requires every work unit in the university to be open, cooperative, and ready to be audited by the internal auditors that have been trained in quality management audit. DIECI management model have been implemented by leading universities in Indonesia. Management strategies, which is part of university's autonomy, should be developed to achieve the targeted quality standard, in line with the national standard of education. DIECI model should be a reference to improve the quality in universities, and the development process, implementation, monitoring, and evaluation should always follow the existing standard operational procedure. When internal quality management improves, it will positively affect external quality management. Therefore, it is important that all programs be ready to undergo accreditation process and to improve external quality management.

\section{REFERENCES}

[1] P.B.A. Wismaya, "Pengaruh Sistem Penjaminan Mutu Internal dan Sistem Manajemen Mutu ISO 9001: 2008 Terhadap Kinerja Organisas di Universitas Warmadewa," Public Inspiration: Jurnal Administrasi Publik, vol. 1, no. 1, pp. 65-80, 2016

[2] H.V. Raghu, "Undang-Undang No 12 Tahun 2012 tentang Pendidikan Tinggi," pp. 37-39, 2012.

[3] Kemenristekdikti, "Permenristekdikti No 62/2016 tentang SPMI," pp. 18,2016

[4] LPPM, Kebijakan SPMI UNIPAS MOROTAI, no. revisi 1, pp. 1-19, 2018.

[5] L.D.W. XII, Klasterisai dan Peringkat Perguruan Tinggi di Maluku dan Maluku Utara, pp. 1-5, 2020.

[6] A.U. Morotai, Dokumen Akademik, Unipas Press, 2020.

[7] L. Lakhal, F. Pasin and M. Limam, "Quality management practices and their impact on performance," Int. J. Qual. Reliab. Manag., vol. 23, no. 6, pp. 625-646, 2006

[8] L. Morley, Quality and Power in Higher Education. Philadelphia: SRHE and Open University Press, 2003.

[9] R. Brown, Quality assurance in higher education: The UK experience since 1992. New York: Taylor \& Francis Group, 2004

[10] A. Arwildayanto, Manajemen Sumber Daya Manusia Perguruan Tinggi. Bandung: Alfabeta, 2013.

[11] U. Husaini, Manajemen Teori, Praktik, dan Riset Pendidikan. Jakarta: Bumi Aksara, 2014

[12] J. Creswell, Research Design, Terjemahan Fawaid Achmad. 2015 Pendekatan Kualitatif, Kuantitatif, dan Mixed. Yogyakarta: Pustaka Pelajar, 2015

[13] S. Sugiyono, Statistika untuk Penelitian. Bandung: Alfabeta, 2015.

[14] I. Othman, S. Norfarahhanim Mohd Ghani and S. Woon Choon, "The Total Quality Management (TQM) journey of Malaysian building contractors," Ain Shams Eng. J., vol. 11, no. 3, pp. 697-704, 2019.

[15] H.J. Harrington, F. Voehl and H. Wiggin, "Applying TQM to the construction industry," TQM J., vol. 24, no. 4, pp. 352-362, 2012.

[16] Dikti, Sistem Penjaminan Mutu Internal Perguruan Tinggi, 2009.

[17] F. Díez, A. Villa, A.L. López and I. Iraurgi, "Impact of quality management systems in the performance of educational centers educational policies and management processes," Heliyon, vol. 6, no. 4, 2020 . 